\title{
PENGARUH SISTEM OLAH TANAH DAN PEMBERIAN HERBISIDA TERHADAP KEHILANGAN UNSUR HARA DAN BAHAN ORGANIK AKIBAT EROSI PADA PERTANAMAN JAGUNG MUSIM TANAM KETIGA DI LABORATORIUM LAPANG TERPADU UNIVERSITAS LAMPUNG
}

\author{
Dicky Chandra, Irwan Sukri Banuwa, Nur Afni Afrianti \& Afandi \\ Jurusan Agroteknologi, Fakultas Pertanian, Universitas Lampung \\ Jl. Prof. Soemantri Brojonegoro, No. 1 Bandar Lampung 35145 \\ Email: cdicky112@gmail.com
}

\begin{abstract}
ABSTRAK
Pengolahan tanah merupakan kegiatan yang dilakukan untuk penyiapan lahan dengan tujuan memperbaiki sifat fisik tanah. Pada prinsipnya pengolahan tanah ada dua yaitu konvensional/intensif dan konservasi/minimum. Pengolahan tanah yang dilakukan secara intensif dapat menimbulkan degradasi. Penyebab degradasi yang paling utama adalah erosi. Erosi akan membawa partikel tanah yang mengandung unsur hara dan bahan organik. Penelitian ini dilaksanakan pada Oktober 2016 sampai Februari 2017 di Laboratorium Lapang Terpadu dan Laboratorium Ilmu Tanah, Fakultas Pertanian, Universitas Lampung. Penelitian ini bertujuan untuk mengetahui pengaruh sistem olah tanah dan pemberian herbisida terhadap kehilangan unsur hara (N, P, K, Ca, Mg) dan bahan organik akibat erosi pada pertanaman jagung. Rancangan yang digunakan yaitu Rancangan Acak Kelompok Lengkap (RAKL) dengan dua faktor perlakuan yaitu sistem olah tanah dan pemberian herbisida dengan empat kali ulangan. Hasil analisis ragam menunjukkan bahwa N-total, P-tersedia, K-dd, Ca-dd, dan C-organik tidak berbeda nyata pada pengolahan tanah, pemberian herbisida, maupun interaksi keduanya dalam sedimen akibat erosi, sedangkan $\mathrm{Mg}$ dd berbeda nyata pada perlakuan pengolahan tanah. Pada olah tanah minimum konsentrasi Mg-dd yang hilang sebesar 0,8187 me per $100 \mathrm{~g}$ dan olah tanah intensif 0,8013 me per $100 \mathrm{~g}$, sehingga kehilangan Mg-dd pada olah tanah minimum lebih besar dari olah tanah intensif.
\end{abstract}

Kata kunci : Erosi, herbisida, pengolahan tanah, unsur hara

\section{PENDAHULUAN}

Jagung (Zea mays L.) merupakan salah satu komoditas bahan pangan yang penting di Indonesia karena jagung merupakan sumber karbohidrat kedua setelah beras. Kebutuhan jagung di Indonesia untuk konsumsi meningkat sekitar 5,16\% per tahun sedangkan untuk kebutuhan pakan ternak dan bahan baku industri naik sekitar 10,87\% per tahun (Roesmarkam dan Yuwono, 2002 dalam Ekowati, 2011).

Kebutuhan jagung yang terus meningkat tersebut menyebabkan perlu adanya peningkatan produksi agar permintaan jagung dapat terpenuhi. Salah satu upaya yang dapat dilakukan untuk meningkatkan produksi adalah melalui peningkatan produktivitas lahan dengan cara pengolahan tanah. Pengolahan tanah merupakan tindakan mekanik terhadap tanah yang ditujukan untuk menyiapkan tempat tumbuh bagi bibit, menciptakan daerah perakaran yang baik, dan memberantas gulma (Arsyad, 2010). Pengolahan tanah yang dilakukan secara intensif dapat memicu terjadinya degradasi.
Degradasi tanah ditandai dengan menurunnya kualitas tanah. Penyebab degradasi tanah salah satunya adalah erosi. Erosi merupakan hilangnya tanah atau bagian-bagian tanah dari suatu tempat yang diangkut air atau angin ke tempat lain (Arsyad, 2010). Proses terjadinya erosi melalui dua proses yaitu penghancuran dan pengangkutan partikel-partikel tanah (Banuwa, 2013).

Erosi yang terjadi pada suatu lahan akan mengangkut tanah dan menghasilkansedimen. Konsentrasi unsur hara di dalam sedimen dapat mencapai 50\% lebih tinggi daripada konsentrasinya pada tanah asal (Wischmeier dan Smith, 1978 dalam Banuwa, 2013). Hal tersebut menunjukkan bahwa sedimen erosi mengangkut banyak unsur hara dan bahan organik tanah, akibatnya lahan yang mengalami erosi akan kekurangan unsur hara dan bahan organik tanah sehingga tidak mampu menyuplai kebutuhan tanaman. Usaha yang dilakukan untuk mengatasi masalah tersebut dapat menggunakan prinsip olah tanah konservasi (OTK), salah satunya yaitu olah tanah minimum. 
Olah tanah minimum (OTM) merupakan salah satu cara pengelolaan tanah dengan melakukan pengolahan tanah seminimal mungkin tetapi masih memberikan kondisi yang menguntungkan bagi pertumbuhan tanaman (Sutanto, 2002). Pada olah tanah minimum, tanah diolah hanya pada bagian penanaman tanaman, sedangkan areal yang tidak dilakukan pengolahan biasanya akan ditumbuhi banyak gulma. Pada olah tanah minimum juga dilakukan pengendalian gulma.

Pengendalian gulma pada olah tanah minimum dapat dilakukan secara manual (dibesik) apabila pertumbuhan gulma tidak terlalu banyak, tetapi apabila pengendalian manual tidak berhasil mengendalikan pertumbuhan gulma, maka dapat dipadukan dengan penggunaan herbisida (Utomo, 2012). Herbisida adalah bahan kimia atau kultur hayati yang dapat menghambat bahkan mematikan gulma (Sembodo, 2010). Gulma yang mati oleh herbisida dapat berfungsi sebagai mulsa, sehingga dapat menghambat kehilangan air melalui evaporasi, dan mencegah erosi (Muzaiyanah dan Harsono, 2015). Gulma yang mati juga akan mengalami pelapukan dan mineralisasi menjadi unsur hara yang tersedia untuk diserap tanaman (Adnan, dkk., 2012).

Berdasarkan uraian di atas, maka perlu dilakukan penelitian tentang pengaruh sistem olah tanah dan pemberian herbisida terhadap kehilangan unsur hara dan bahan organik akibat erosi pada pertanaman jagung (Zea mays L.) di Laboratorium Lapang Terpadu Fakultas Pertanian Universitas Lampung. Penelitian ini bertujuan untuk mengetahui pengaruh sistem olah tanah dan pemberian herbisida terhadap kehilangan unsur hara dan bahan organik akibat erosi pada pertanaman jagung.

\section{BAHAN DAN METODE}

Penelitian ini dilaksanakan pada bulan Oktober 2016 sampai bulan Februari 2017 di Laboratorium Lapang Terpadu dan Laboratorium Ilmu Tanah, Fakultas Pertanian Universitas Lampung. Bahan yang digunakan yaitu benih jagung, herbisida (isopropilamina glifosat $240 \mathrm{~g} \mathrm{l}^{-1}$ ), pupuk Urea, pupuk SP-36, pupuk KCl, pupuk kompos, kantong plastik, dan bahan lain yang digunakan untuk keperluan analisis di laboratorium. Alat yang digunakan yaitu petak erosi ukuran $4 \mathrm{~m} \mathrm{x} 4 \mathrm{~m}$, pengukur erosi atau sedimen (saringan dan sendok), pengukur aliran permukaan (gelas ukur), pengukur curah hujan (ombrometer), sprayer, cangkul, dan alat-alat yang digunakan pada analisis laboratorium.

Metode pengukuran erosi menggunakan metode pengukuran untuk satu kejadian hujan pada petak-petak kecil (multislot deviser). Penelitian ini menggunakan rancangan faktorial dalam Rancangan Acak Kelompok Lengkap (RAKL) pada dua faktor perlakuan yaitu sistem olah tanah, yakni M (olah tanah minimum) dan F (olah tanah intensif) serta perlakuan herbisida yaitu pemberian herbisida dan tanpa pemberian herbisida.

Penelitian ini merupakan penelitian lanjutan dan merupakan penelitian pada musim tanam ketiga. Penelitian musim tanam pertama dilaksanakan pada bulan Januari 2014 sampai April 2014 dengan tanaman jagung, selanjutnya pada bulan Mei 2014 sampai April 2015 dengan tanaman singkong.Penelitian musim tanam kedua dilaksanakan pada bulan Mei 2015 sampai Agustus 2015 dengan tanaman jagung, selanjutnya bulan Oktober 2015 sampai September 2016 dengan tanaman singkong.

Penelitian ini dilakukan empat kali pengulangan sehingga didapatkan 16 satuan percobaan. Setiap satuan percobaannya ditempatkan pada petak erosi ukuran $4 \mathrm{~m} \times 4 \mathrm{~m}=16 \mathrm{~m}^{2}$ dengan dinding yang terbuat dari beton pada kemiringan lereng $12,5 \%$. Pada bagian depan atau bawah petak erosi terdapat bak berukuran $100 \mathrm{~cm}$ $\times 50 \mathrm{~cm} \times 50 \mathrm{~cm}$ yang berfungsi untuk penampung aliran permukaan dan tanah yang tererosi. Bak tersebut memiliki 5 buah lubang yang berfungsi untuk saluran pembuangan apabila volume air yang ada pada bak erosi terlalu banyak. Lubang yang berada ditengah bak disalurkan menuju sebuah drum penampung yang berfungsi untuk mengukur besarnya jumlah aliran permukaan.

Besarnya aliran permukaan dihitung dengan menjumlahkan volume air di dalam bak dengan volume air yang ada di dalam drum dikalikan lima. Volume air yang ada di dalam drum dikalikan lima karena terdapat lima buah saluran pembuangan. Bak dan drum tersebut kemudian ditutup dengan rapat agar tidak tercampur dengan air hujan sehingga data yang akan diperoleh lebih akurat. Gambar petak, bak, dan drum dapat dilihat pada Gambar 1. Pelaksanaan penelitian ini yaitu dengan melakukan olah tanah intensif (full tillage) dan olah

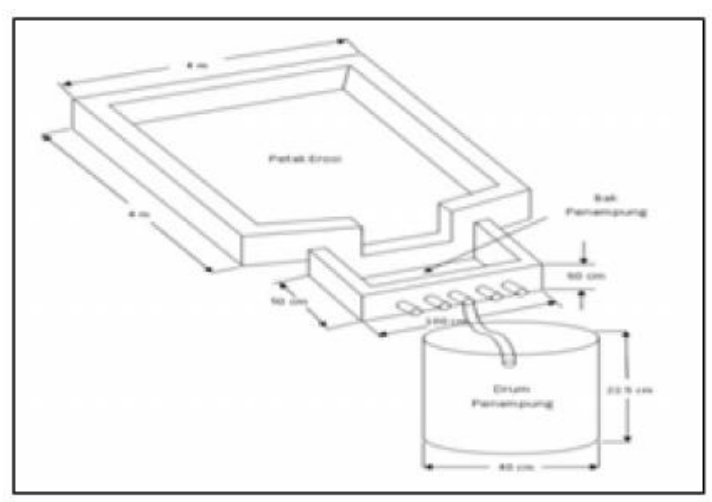

Gambar 1. Kontruksi Pengukur Erosi 
tanah minimum (minimum tillage). Olah tanah intensif merupakan pengolahan tanah dengan membolak balikkan tanah hingga tanah menjadi gembur dan dibuat guludan-guludan, sedangkan olah tanah minimum yaitu pengolahan tanah yang dilakukan hanya pada lubang tanam dan permukaan tanah diberikan mulsa berupa sisa tanaman musim sebelumnya.

Selanjutnya yaitu penanaman. Tanaman yang digunakan adalah jagung. Setiap perlakuannya diberi pupuk urea sebanyak $300 \mathrm{~kg} \mathrm{ha}^{-1}$, SP-36 $100 \mathrm{~kg} \mathrm{ha}^{-1}$, $\mathrm{KCl} 200 \mathrm{~kg} \mathrm{ha}^{-1}$, dan 10 ton ha ${ }^{-1}$ kompos organonitrofos. Penyemprotan herbisida dilakukan pada perlakuan pemberian herbisida.

Pengumpulan data dilakukan dengan mengamati curah hujan, pengukuran jumlah sedimen, serta analisis unsur hara dan bahan organik dalam tanah asal dan dalam sedimen.

Curah Hujan. Pengukuran curah hujan dilakukan dengan menghitung jumlah volume air pada Ombrometer yang dilakukan keesokan paginya setelah terjadi hujan. Hasil pengukuran curah hujan dinyatakan dalam satuan milimeter ( $\mathrm{mm}$ ).

Erosi. Pengukuran jumlah tanah tererosi dilakukan keesokan harinya setiap kali terjadi hujan dengan cara mengambil tanah yang mengendap di dalam bak erosi, kemudian ditimbang untuk mengetahui jumlah berat basahnya. Setelah itu diambil sampel tanah dan dikeringkan dengan oven untuk menganalisis kadar air tanah. Selanjutnya dihitung bobot total tanah yang tererosi setiap terjadi hujan. Erosi yang terjadi dinyatakan dalam $\mathrm{kg} \mathrm{ha}^{-1}$.

Analisis Unsur Hara dan Bahan Organik. Unsur yang dianalisis adalah N-Total, P-Tersedia, Kdd, Ca-dd, Mg-dd, dan C-Organik, pada tanah asal, sedimen erosi, selanjutnya didapatkan nisbah pengayaan yang merupakan perbandingan konsentrasi unsur hara dalam sedimen dengan konsentrasi pada tanah asalnya.

Data yang diperoleh kemudian dianalisis dengan sidik ragam, yang sebelumnya homogenitas data dianalisis dengan uji Bartlet dan aditivitas data diuji dengan uji Tukey. Kemudian perbedaan nilai tengah diuji dengan uji Beda Nyata Terkecil (BNT) pada taraf 5\%.

\section{HASIL DAN PEMBAHASAN}

Konsentrasi Unsur Hara dan Bahan Organik. Analisis ragam terhadapunsur hara N, P, K,Ca dan COrganik pada perlakuan pengolahan tanah, pemberian herbisida, dan kombinasi keduanya tidak memberikan pengaruh nyata terhadap konsentrasinya dalam sedimen, sedangkan uji nilai tengah $\mathrm{N}$-total, $\mathrm{P}$-tersedia, $\mathrm{K}$-dd, Cadd, dan C-Organik disajikan pada Tabel 1. Analisis ragam $\mathrm{Mg}$-dd berpengaruh nyata pada perlakuan pengolahan tanah, sedangkan herbisida tidak berpengaruh nyata. Hasil uji BNT taraf 5\% konsentrasi Mg-dd dalam sedimen disajikan pada Tabel 2 dan Gambar 2.

Uji nilai tengah pada penelitian ini menunjukkan bahwa pada variabel N-total, P-tersedia, K-dd, Ca-dd, dan C-Organik tidak berbeda nyata baik pada perlakuan olah tanah, pemberian herbisida, maupun interaksi keduanya dalam sedimen yang diakibatkan oleh erosi (Tabel 1). Hasil penelitian ini sama dengan hasil penelitian yang dilakukan oleh Banuwa, dkk. (2014) pada pertanaman yang sama di musim tanam pertama yang menunjukkan bahwa pada perlakuan olah tanah, pemberian herbisida, dan interaksi keduanya tidak berbeda nyata pada konsentrasi N, P, K, Ca dan COrganik dalam sedimen.

Kehilangan unsur hara dan bahan organik yang tidak berbeda nyata tersebut, dikarenakan erosi yang terjadi tidak berbeda nyata. Erosi yang tidak berbeda nyata dapat disebabkan karena erosi yang tidak bersifat selektif. Selektifitas erosi merupakan sifat khas dari erosi yang berhubungan dengan energi pengerosinya (Banuwa, 2013). Energi pengerosi pada penelitian ini berasal dari aliran permukaan saat terjadi hujan. Kapasitas transportasi aliran permukaan sangat mempengaruhi sifat selektif erosi (Banuwa, 2016).

Aliran permukaan yang didapat pada penelitian ini tidak berbeda nyata menurut Uji BNT taraf $5 \%$. Aliran permukaan yang tidak berbeda nyata tersebut menunjukkan bahwa perlakuan atau tindakan konservasi yang dilakukan tidak mempengaruhi laju aliran permukaan saat terjadi hujan. Hasil ini menunjukkan bahwa erosi yang terjadi tidak bersifat selektif, sehingga erosi yang dihasilkan tidak berbeda nyata antar perlakuan. Erosi yang tidak berbeda nyata antar perlakuan tersebut juga akan membawa unsur hara dan bahan organik tanah yang tidak berbeda nyata dalam sedimennya.

Erosi yang tidak berbeda nyata antar perlakuan juga disebabkan karena curah hujan yang rendah selama penelitian. Curah hujan yang didapat pada penelitian bulan Oktober sebesar 35,55 mm, bulan November 51,27 $\mathrm{mm}$, bulan Desember 20,94 mm, dan bulan Januari 52,35 mm. Penggolongan iklim menurut Mohr (1993 dalam Kartasapoetra, 2006) didasarkan atas bulan basah dan bulan kering, dikatakan bulan basah jika curah hujan melebihi $100 \mathrm{~mm}$ sedangkan bulan kering apabila curah hujan kurang dari $60 \mathrm{~mm}$. Berdasarkan penggolongan iklim tersebut, curah hujan selama penelitian ini digolongkan bulan kering, karena curah hujan bulanan yang kurang dari $60 \mathrm{~mm}$. Hal ini menunjukkan curah 
Tabel 1. Uji nilai tengah pengaruh sistem olah tanah dan pemberian herbisida terhadap konsentrasi unsur hara dan bahan organik dalam sedimen.

\begin{tabular}{|c|c|c|c|c|c|c|}
\hline \multirow{3}{*}{ Perlakuan } & \multicolumn{6}{|c|}{ Unsur Hara } \\
\hline & \multicolumn{2}{|c|}{ N-Total (\%) } & \multirow{2}{*}{$\begin{array}{l}\text { P-Tersedia } \\
\quad(\mathrm{ppm})\end{array}$} & \multirow{2}{*}{$\begin{array}{c}\text { K-dd } \\
\text { (me per } 100 \mathrm{~g})\end{array}$} & \multirow{2}{*}{$\begin{array}{c}\text { Ca-dd } \\
\text { (me per } 100 \mathrm{~g} \text { ) }\end{array}$} & \multirow{2}{*}{$\begin{array}{c}\text { C-Organik } \\
(\%)\end{array}$} \\
\hline & Asli & Trans*) & & & & \\
\hline FH0 & 0,13 & $7,65 \mathrm{a}$ & $40,04 a$ & $0,63 a$ & $1,02 \mathrm{a}$ & $1,61 \mathrm{a}$ \\
\hline FH1 & 0,13 & $8,13 \mathrm{a}$ & $37,52 \mathrm{a}$ & $0,50 \mathrm{a}$ & $0,98 \mathrm{a}$ & $1,47 \mathrm{a}$ \\
\hline MH0 & 0,15 & $8,69 \mathrm{a}$ & $41,94 a$ & $0,65 \mathrm{a}$ & $0,98 \mathrm{a}$ & $1,49 a$ \\
\hline MH1 & 0,14 & $7,64 \mathrm{a}$ & $39,04 a$ & $0,63 \mathrm{a}$ & $1,03 \mathrm{a}$ & $1,54 \mathrm{a}$ \\
\hline BNT 5\% & & 2,96 & 10,16 & 0,11 & 0,08 & 0,23 \\
\hline
\end{tabular}

Keterangan: *) Nilai hasil transformasi inverse (1/x) dan angka-angka yang diikuti oleh huruf yang sama tidak berbeda nyata berdasarkan uji BNT taraf 5\%, MH0 = Olah Tanah Minimum, FH0 = Olah Tanah Intensif, dan MH1 = Minimum + Herbisida, dan FH1 = Intensif + Herbisida

Tabel 2. Hasil pengaruh sistem olah tanah dan pemberian herbisida terhadap konsentrasi Mg-dd dalam sedimen.

\begin{tabular}{cc}
\hline Perlakuan & Konsentrasi Mg-dd (me per 100g) \\
\hline F & 0,8013 a \\
M & $0,8187 \mathrm{~b}$ \\
\hline Nilai BNT 5\% & 0,01 \\
\hline H0 & 0,8125 a \\
H1 & 0,8075 a \\
\hline Nilai BNT 5\% & 0,01 \\
\hline
\end{tabular}

Keterangan: $\mathrm{M}=$ Olah Tanah Minimum, $\mathrm{F}=$ Olah Tanah Intensif, $\mathrm{H} 0=$ Tanpa Pemberian Herbisida, $\mathrm{H} 1=$ Pemberian Herbisida

hujan yang rendah pada penelitian ini, sehingga penghancuran partikel-partikel tanah akibat energi kinetik air hujan menjadi rendah. Curah hujan yang rendah juga menyebabkan air masih dapat mengalami infiltrasi yang akan berdampak terhadap rendahnya laju aliran permukaan antar perlakuan dan diperoleh hasil yang tidak berbeda nyata menurut uji BNT taraf 5\%. Aliran permukaan yang rendah dan tidak berbeda nyata antar perlakuan tersebut menyebabkan erosi yang terjadi juga tidak berbeda nyata antar perlakuannya.

Analisis ragam penelitian ini juga menunjukkan bahwa pada variabel $\mathrm{Mg}$-dd berbeda nyata pada perlakuan olah tanah (Tabel 2). Uji BNT yang dilakukan diperoleh hasil pada perlakuan olah tanah intensif 0,8013 me per $100 \mathrm{~g}$, sedangkan olah tanah minimum 0,8187 me per $100 \mathrm{~g}$. Hasil ini menunjukkan bahwa konsentrasi Mg-dd olah tanah minimum lebih besar dibandingkan olah tanah intensifpada sedimen erosi. Kehilangan unsur hara yang lebih tinggi pada olah tanah minimum tersebut terjadi karena erosi dan aliran permukaan pada olah tanah minimum lebih kecil dibandingkan olah tanah intensif, meskipun tidak berbeda nyata menurut uji BNT taraf 5\%. Menurut Banuwa (2016), pada lahan usahatani yang erosinya kecil, jumlah partikel-partikel tanah halus lebih besar dalam sedimen, sehingga banyak mengikat unsur hara.

Kehilangan unsur hara $\mathrm{Mg}$ yang lebih tinggi pada olah tanah minimum tersebut juga sejalan dengan kehilangan unsur $\mathrm{K}$ dan $\mathrm{Ca}$ yang cenderung lebih tinggi pada perlakuan olah tanah minimum dibandingkan olah tanah intensif meskipun berdasarkan analisis ragam kedua unsur ini menunjukkan hasil yang tidak berbeda nyata. Kation-kation dalam tanah, seperti K, Ca dan Mg dijerap dengan kekuatan yang berbeda-beda. 


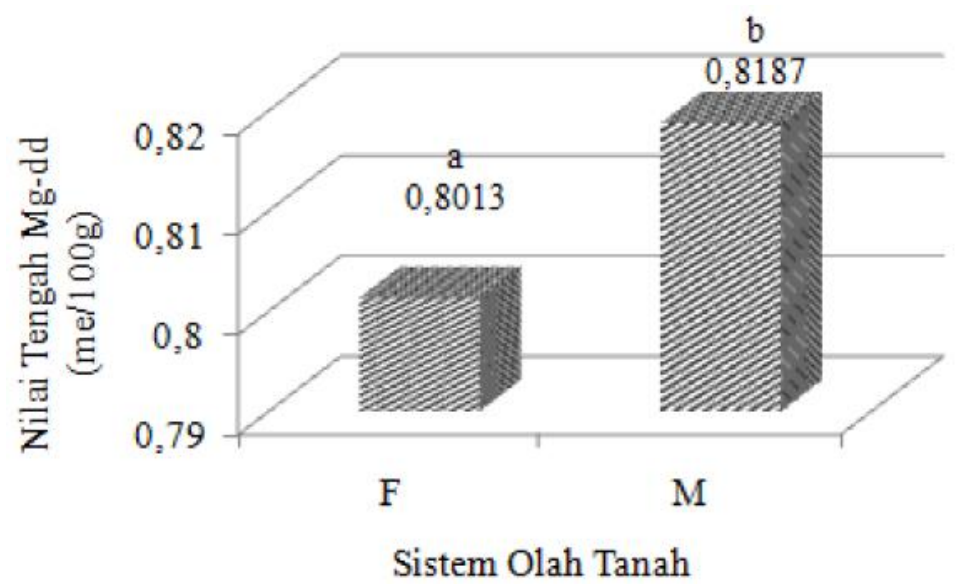

Gambar 2. Pengaruh sistem olah tanah terhadap konsentrasi Mg-dd dalam sedimen. $\mathrm{F}=$ olah tanah intensif, $\mathrm{M}=$ olah tanah minimum.

Kekuatan jerapan dipengaruhi oleh valensi kation dan daya hidrasi kation. Semakin tinggi valensi kation, semakin kuat dijerap koloid tanah dan semakin rendah daya hidrasi kation maka semakin kuat kation dijerap koloid tanah. Urutan kekuatan kation dijerap koloid yaitu $\mathrm{Al}^{3+}>\mathrm{Ca}^{2+}>\mathrm{Mg}^{2+}>\mathrm{K}^{+}>\mathrm{Na}^{+}$(Utomo, 2016). Berdasarkan kekuatan jerapan kation tersebut, kation $\mathrm{K}, \mathrm{Ca}$, dan $\mathrm{Mg}$ cenderung lemah dijerap oleh koloid tanah, akibatnya mudah hilang terbawa aliran permukaan saat terjadi erosi. Hal ini didukung oleh Lumbanraja (2013) yang menyatakan bahwa unsur hara $\mathrm{K}, \mathrm{Ca}$, dan $\mathrm{Mg}$ tergolong unsur yang mudah larut dalam air, selain itu Gardiner dan Miller (2008 dalam Utomo, 2016) juga menyatakan bahwa unsur hara makro kation yang mudah tercuci adalah basa-basa $\mathrm{K}$, $\mathrm{Ca}$, dan $\mathrm{Mg}$. Unsur hara $\mathrm{Mg}$ berasal dari proses pelapukan mineral yang mengandung $\mathrm{Mg}$. Proses tersebut menyebabkan Mg tersedia bebas di dalam tanah (Hakim, dkk., 1986 dalam Banjarnahor, 2010). Pada olah tanah minimum, sisa tanaman musim tanam sebelumnya dikembalikan ke lahan. Gulma yang tumbuh pada perlakuan olah tanah minimum lebih banyak dibandingkan olah tanah intensif karena pengolahan yang hanya dilakukan pada bagian yang akan ditanami saja.

Gulma pada olah tanah minimum dilakukan pengendalian secara manual dan hasil pengendaliannya dibiarkan di lahan. Unsur Mg berperan dalam pembentukan molekul klorofil (Utomo, dkk., 2016). Hal tersebut menunjukkan bahwa klorofil mengandung banyak unsur Mg. Hasil pelapukan sisa tanaman musim tanam sebelumnya dan gulma yang mengandung molekul klorofil pada olah tanah minimum akan memberikan kandungan $\mathrm{Mg}$ yang lebih tinggi dibandingkan olah tanah intensif. Akibatnya saat terjadi erosi unsur $\mathrm{Mg}$ pada olah tanah minimum lebih banyak yang dapat terbawa dalam sedimennya.
Olah tanah minimum diberikan mulsa untuk menghambat laju erosi, namun hasil penelitian pemberian mulsa pada olah tanah minimum tidak mampu menekan laju aliran permukaan sehingga erosi yang dihasilkan tidak berbeda nyata. Hal tersebut karena penggunaan mulsa pada penelitian ini masih terlalu sedikit pada perlakuan olah tanah minimum. Menurut Utomo (2015) penggunaan mulsa pada olah tanah minimum agar dapat menekan erosi, berkisar 6-8 ton ha ${ }^{-1}$ dan $30 \%$ untuk menutupi permukaan tanah.

Perlakuan herbisida menunjukkan bahwa pada variabel $\mathrm{N}$-total, P-tersedia, $\mathrm{K}$-dd, Ca-dd, Mg-dd, dan C-organik tidak berbeda nyata antara pemberian herbisida dan tanpa pemberian herbisida. Hasil ini terjadi karena gulma yang mati pada pemberian herbisida tidak mampu menekan erosi yang terjadi, yang juga akan berdampak terhadap kehilangan unsur hara.

Nisbah Pengayaan. Nisbah pengayaan didapatkan melalui perhitungan dengan membandingkan konsentrasi unsur hara pada sedimen yang tererosi dengan tanah asalnya (Sinukaban 1981, dalam Banuwa 1994). Besarnya nisbah pengayaan bergantung dengan konsentrasi unsur hara dan bahan organik dalam sedimen yang dibawa oleh erosi. Semakin besar konsentrasi unsur hara dan bahan organik yang dibawa oleh erosi, akan semakin besar pula kehilangan unsur hara dan bahan organiknya. Berbanding lurus dengan hal tersebut, maka sedimen akan mengandung unsur hara dan bahan organik yang lebih tinggi dibandingkan dengan tanah asalnya. Pengayaan ini berasal dari sifat selektifitas erosi terhadap partikel-partikel tanah yang lebih halus (Banuwa, 2013).

Erosi bersifat selektif apabila erosi yang terjadi kecil. Artinya apabila aliran permukaan yang membawa erosi banyak dihambat oleh adanya tindakan-tindakan 
Tabel 3. Hasil uji BNT 5\% pada nisbah pengayaan terhadap konsentrasi N-Total, P-Tersedia, K-dd, Ca-dd, dan C-Organik.

\begin{tabular}{|c|c|c|c|c|c|c|c|}
\hline \multirow{3}{*}{ No } & \multirow{3}{*}{ Perlakuan } & \multicolumn{6}{|c|}{ Unsur Hara } \\
\hline & & \multicolumn{2}{|c|}{ N-Total $(\%)$} & \multirow{2}{*}{$\begin{array}{l}\text { P-Tersedia } \\
\quad(\mathrm{ppm})\end{array}$} & \multirow{2}{*}{$\begin{array}{c}\text { K-dd } \\
(\text { me per } 100 \mathrm{~g})\end{array}$} & \multirow{2}{*}{$\begin{array}{c}\text { Ca-dd } \\
\text { (me per } 100 \mathrm{~g})\end{array}$} & \multirow{2}{*}{$\begin{array}{c}\text { C-Organik } \\
(\%)\end{array}$} \\
\hline & & Asli & Trans $*)$ & & & & \\
\hline 1 & FH0 & 0,88 & $1,15 \mathrm{a}$ & $0,80 \mathrm{a}$ & $1,03 a$ & $1,09 a$ & $1,04 \mathrm{a}$ \\
\hline 2 & FH1 & 0,83 & $1,22 \mathrm{a}$ & $0,75 \mathrm{a}$ & $0,82 \mathrm{a}$ & $1,04 \mathrm{a}$ & $0,95 \mathrm{a}$ \\
\hline 3 & MHO & 0,98 & $1,30 \mathrm{a}$ & $0,84 a$ & $1,06 a$ & $1,04 \mathrm{a}$ & $0,96 \mathrm{a}$ \\
\hline 4 & MH1 & 0,92 & $1,15 \mathrm{a}$ & $0,78 \mathrm{a}$ & $1,04 \mathrm{a}$ & $1,09 \mathrm{a}$ & $1,00 \mathrm{a}$ \\
\hline \multicolumn{2}{|c|}{ Nilai BNT 5\% } & & 0,44 & 0,20 & 0,18 & 0,08 & 0,15 \\
\hline
\end{tabular}

Keterangan: *) Nilai hasil transformasi inverse (1/x) dan angka-angka yang diikuti huruf yang sama, tidak berbeda pada taraf nyata $5 \%$ menurut uji beda nyata terkecil

Tabel 4. Hasil uji BNT 5\% pada nisbah pengayaan terhadap konsentrasi Mg-dd

\begin{tabular}{cc}
\hline Perlakuan & Konsentrasi Mg-dd (me per 100g) \\
\hline F & $0,9892 \mathrm{a}$ \\
M & $1,0108 \mathrm{~b}$ \\
\hline Nilai BNT 5\% & 0,01 \\
\hline H0 & $1,0031 \mathrm{a}$ \\
H1 & $0,9969 \mathrm{a}$ \\
\hline Nilai BNT 5\% & 0,01 \\
\hline
\end{tabular}

Keterangan: $\mathrm{M}=$ Olah Tanah Minimum, $\mathrm{F}=$ Olah Tanah Intensif, $\mathrm{H} 0=$ Tanpa Pemberian Herbisida, $\mathrm{H} 1=$ Pemberian Herbisida

konservasi tanah, menyebabkan aliran permukaan juga menjadi lebih lambat sehingga sedimen yang terangkut oleh erosi akan terdeposisi. Kemungkinan lain, meskipun aliran permukaan tetap berlangsung dengan kecepatan yang besar sekalipun, tetapi sedimen hasil erosi yang terangkut secara mekanis akan dipaksa untuk dideposisi sepanjang lintasan aliran permukaan, khususnya partikelpartikel yang berukuran besar dan berat (Banuwa, 2016). Tindakan konservasi tanah dapat dilakukan dengan pengolahan tanah, salah satunya dengan olah tanah minimum.

Pengaruh sistem olah tanah dan pemberian herbisida terhadap nisbah pengayaan pada variabel $\mathrm{N}$ Total, P-Tersedia, K-dd, Ca-dd, dan C-Organik disajikan pada Tabel 3, sedangkan hasil analisis ragam nisbah pengayaan yang dilakukan pada variabel $\mathrm{Mg}$-dd menunjukkan bahwa perlakuan pengolahan tanah memberikan pengaruh nyata dan perlakuan herbisida tidak memberikan pengaruh nyata. Uji BNT taraf 5\% nisbah pengayaan variabel $\mathrm{Mg}$-dd disajikan pada Tabel 4.

Nilai nisbah pengayaan (NP) yang didapatkan kurang dari satu $(<1)$ maka konsentrasi unsur hara yang terdapat dalam sedimen lebih rendah dari konsentrasi unsur hara pada tanah asalnya. Nilai NP yang sama dengan satu $(=1)$ berarti konsentrasi unsur hara pada sedimen sama dengan konsentrasi unsur hara pada tanah asal. Nilai NP lebih dari satu ( $>1)$ menunjukkan bahwa konsentrasi unsur hara dalam sedimen lebih tinggi dari konsentrasi unsur hara yang terkandung pada tanah asalnya (Burhannudin, 2015).

Nilai NP yang didapatkan pada penelitian ini yang lebih dari satu (>1) yaitu perlakuan FH0, MH0, MH1 pada variabel K-dd, perlakuan FH0, FH1, MH0, MH1 pada variabel Ca-dd, dan $\mathrm{FH} 0$ pada variabel C-organik. Hasil tersebut menunjukkan bahwa konsentrasi unsur hara dalam sedimen lebih tinggi dibandingkan tanah asalnya. 
Nilai NP penelitian ini yang sama dengan satu (=1) didapatkan pada perlakuan MH1 dengan variabel C-Organik. Hasil ini menunjukkan bahwa pada perlakuan dan variabel tersebut, konsentrasi unsur hara dalam sedimen sama dengan tanah asalnya.

Nilai NP kurang dari satu $(<1)$ didapatkan pada perlakuan FH0, FH1, MH0, MH1pada variabel N-total, perlakuan FH0, FH1, MH0, MH1 pada P-tersedia, perlakuan $\mathrm{FH} 1$ pada $\mathrm{K}$-dd,dan pada C-organik dengan perlakuan FH1 dan MH0. Hasil ini menunjukkan bahwa konsentrasi unsur hara dalam sedimen lebih kecil dibandingkan tanah asalnya.

Nilai NP perlakuan olah tanah minimum (OTM) dan olah tanah intensif (OTI) secara keseluruhan pada variabel N-Total, P-Tersedia, K-dd, Ca-dd, dan Corganik tidak berbeda nyata menurut uji BNT taraf $5 \%$. Hasil ini disebabkan erosi yang terjadi tidak bersifat selektif. Erosi yang bersifat selektif terjadi apabila erosi yang terjadi kecil (Banuwa, 2013). Hal tersebut menunjukkan bahwa tindakan konservasi yang dilakukan pada OTM tidak mampu menurunkan laju aliran permukaan secara nyata, sehingga erosi tetap membawa sedimen. Akibatnya erosi yang terjadi antara OTI dan OTM tidak berbeda nyata. Erosi yang tidak berbeda nyata menyebabkan nilai NP yang dihasilkan juga tidak berbeda nyata. Tabel 4 menunjukkan bahwa pada variabel $\mathrm{Mg}$-dd berbeda nyata pada olah tanah. Nilai NP olah tanah minimum lebih besar dibandingkan olah tanah intensif. Hasil ini menunjukkan bahwa konsentrasi Mg-dd dalam sedimen pada olah tanah minimum lebih tinggi dibandingkan olah tanah intensif. Hal tersebut karena erosi pada olah tanah minimum lebih kecil dibandingkan olah tanah intensif, meskipun tidak berbeda nyata menurut uji BNT taraf 5\%. Menurut Banuwa (1994), nilai NP akan meningkat dengan menurunnya tanah tererosi.

Kehilangan Unsur Hara dan Bahan Organik. Erosi akan membawa tanah dan menyebabkan hilangnya unsur hara dan bahan organik tanah dari tanah asal, sehingga tanaman akan kekurangan unsur hara yang dibutuhkan untuk menunjang pertumbuhannya. Banyaknya unsur hara yang terbawa erosi dapat dihitung dengan mengkalikan konsentrasi unsur hara dengan banyaknya tanah yang tererosi (Banuwa, 2013). Besarnya kehilangan unsur hara dan bahan organik akibat erosi pada penelitian ini disajikan pada Tabel 5 dan 6.

Tabel 5 dan 6 menunjukkan bahwa hara yang terangkut pada variabel N-Total, P-Tersedia, K-dd, Cadd, Mg-dd, dan C-organik antar perlakuan pada penelitian ini tidak berbeda nyata menurut uji BNT taraf $5 \%$. Hal ini terjadi karena erosi yang dihasilkan tidak berbeda

Tabel 5. Kehilangan unsur hara N-Total, P-Tersedia, dan K-dd akibat erosi selama penelitian.

\begin{tabular}{|c|c|c|c|c|c|c|}
\hline \multirow{3}{*}{ Perlakuan } & \multicolumn{6}{|c|}{ Hara Yang Terangkut $\left(\mathrm{kg} \mathrm{ha}^{-1}\right)$} \\
\hline & \multicolumn{2}{|c|}{ N-Total } & \multicolumn{2}{|c|}{ P-Tersedia } & \multicolumn{2}{|c|}{ K-dd } \\
\hline & Asli & Trans* & Asli & Trans* & Asli & Trans* \\
\hline FH0 & 0,0345 & $0,4136 a$ & 0,0010 & $0,0302 \mathrm{a}$ & 0,0061 & $0,2701 \mathrm{a}$ \\
\hline FH1 & 0,0617 & $0,4327 \mathrm{a}$ & 0,0022 & 0,0376 a & 0,0111 & $0,2743 \mathrm{a}$ \\
\hline MH0 & 0,0460 & $0,3651 \mathrm{a}$ & 0,0008 & $0,0240 \mathrm{a}$ & 0,0049 & $0,2335 \mathrm{a}$ \\
\hline MH1 & 0,0607 & $0,4164 \mathrm{a}$ & 0,0022 & 0,0363 a & 0,0120 & $0,2737 \mathrm{a}$ \\
\hline BNT 5\% & & 0,29 & & 0,05 & & 0,18 \\
\hline $\mathrm{F}$ & 0,0481 & $0,4231 \mathrm{a}$ & 0,0016 & 0,0339 a & 0,0086 & $0,2722 \mathrm{a}$ \\
\hline M & 0,0534 & 0,3908 a & 0,0015 & $0,0301 \mathrm{a}$ & 0,0084 & $0,2536 a$ \\
\hline BNT 5\% & 0,09 & 0,21 & & 0,03 & & 0,12 \\
\hline HO & 0,0403 & $0,3894 \mathrm{a}$ & 0,0009 & $0,0271 \mathrm{a}$ & 0,0055 & $0,2518 \mathrm{a}$ \\
\hline $\mathrm{H} 1$ & 0,0612 & $0,4245 \mathrm{a}$ & 0,0022 & 0,0369 a & 0,0116 & $0,2740 \mathrm{a}$ \\
\hline BNT 5\% & & 0,21 & & 0,03 & & 0,12 \\
\hline
\end{tabular}

Keterangan: FH0 = Olah Tanah Intensif, FH1 = Intensif + Herbisida, MH0 = Olah Tanah Minimum, MH1 = Minimum + Herbisida, $*$ = Transformasi SQRT 
Tabel 6. Kehilangan unsur hara Ca-dd, Mg-dd, dan C-Organik akibat erosi selama penelitian.

\begin{tabular}{|c|c|c|c|c|c|c|}
\hline \multirow{3}{*}{ Perlakuan } & \multicolumn{6}{|c|}{ Hara Yang Terangkut $\left(\mathrm{kg} \mathrm{ha}^{-1}\right)$} \\
\hline & \multicolumn{2}{|c|}{ Ca-dd } & \multicolumn{2}{|c|}{ Mg-dd } & \multicolumn{2}{|c|}{ C-Organik } \\
\hline & Asli & Trans* & Asli & Trans* & Asli & Trans* \\
\hline FH0 & 0,0051 & $0,0683 \mathrm{a}$ & 0,0024 & $0,0469 \mathrm{a}$ & 0,4234 & $0,7719 \mathrm{a}$ \\
\hline FH1 & 0,0115 & $0,0863 \mathrm{a}$ & 0,0054 & $0,0598 \mathrm{a}$ & 0,7851 & 0,8060 a \\
\hline MH0 & 0,0037 & $0,0523 \mathrm{a}$ & 0,0019 & $0,0370 \mathrm{a}$ & 0,2837 & $0,6474 \mathrm{a}$ \\
\hline MH1 & 0,0100 & $0,0791 \mathrm{a}$ & 0,0047 & $0,0543 \mathrm{a}$ & 0,7435 & $0,7660 \mathrm{a}$ \\
\hline BNT 5\% & & 0,10 & & 0,07 & & 0,50 \\
\hline $\mathrm{F}$ & 0,0083 & $0,0773 \mathrm{a}$ & 0,0039 & $0,0534 \mathrm{a}$ & 0,6043 & $0,7890 \mathrm{a}$ \\
\hline M & 0,0069 & $0,0657 \mathrm{a}$ & 0,0033 & $0,0456 \mathrm{a}$ & 0,5136 & $0,7067 \mathrm{a}$ \\
\hline BNT 5\% & & 0,07 & & 0,05 & & 0,36 \\
\hline $\mathrm{HO}$ & 0,0044 & $0,0603 \mathrm{a}$ & 0,0021 & $0,0420 \mathrm{a}$ & 0,3536 & $0,7096 \mathrm{a}$ \\
\hline $\mathrm{H} 1$ & 0,0107 & $0,0827 \mathrm{a}$ & 0,0051 & $0,0571 \mathrm{a}$ & 0,7643 & 0,7860 a \\
\hline BNT 5\% & & 0,07 & & 0,05 & & 0,36 \\
\hline
\end{tabular}

Keterangan: FH0 = Olah Tanah Intensif, FH1 = Intensif + Herbisida, MH0 = Olah Tanah Minimum, MH1 = Minimum + Herbisida, ${ }^{*}=$ Transformasi SQRT

nyata. Erosi yang tidak berbeda nyata tersebut menyebabkan hara yang terangkut pada sedimen juga tidak berbeda nyata.

Tabel 5 dan 6 juga menunjukkan bahwa pada perlakuan olah tanah minimum $(\mathrm{M})$ variabel N-Total, P-Tersedia, K-dd, Ca-dd, Mg-dd, dan C-Organik yang hilang akibat erosi cenderung lebih kecil dibandingkan perlakuan olah tanah intensif $(\mathrm{F})$. Besarnya kehilangan N-Total, P-Tersedia, K-dd, Ca-dd, Mg-dd, dan C-Organik akibat erosi secara berturut-turut pada olah tanah minimum (M) adalah sebesar $0,0534 \mathrm{~kg} \mathrm{ha}^{-1}, 0,0015 \mathrm{~kg}$ $\mathrm{ha}^{-1}, 0,0084 \mathrm{~kg} \mathrm{ha}^{-1}, 0,0069 \mathrm{~kg} \mathrm{ha}^{-1}, 0,0033 \mathrm{~kg} \mathrm{ha}^{-1}, 0,5136$ $\mathrm{kg} \mathrm{ha}^{-1}$, sedangkan pada olah tanah intensif (F) sebesar $0,0481 \mathrm{~kg} \mathrm{ha}^{-1}, 0,0016 \mathrm{~kg} \mathrm{ha}^{-1}, 0,0086 \mathrm{~kg} \mathrm{ha}^{-1}, 0,0083 \mathrm{~kg}$ $\mathrm{ha}^{-1}, 0,0039 \mathrm{~kg} \mathrm{ha}^{-1}, 0,6043 \mathrm{~kg} \mathrm{ha}^{-1}$. Total kehilangan unsur hara dan bahan organik pada keseluruhan variabel perlakuan olah tanah minimum (M) sebesar $0,5871 \mathrm{~kg}$ ha $^{-1}$, sedangkan olah tanah intensif (F) sebesar 0,6748 $\mathrm{kg} \mathrm{ha}^{-1}$.

Hal tersebut karena perlakuan olah tanah minimum telah mampu menekan erosi, meskipun tidak berbeda nyata menurut uji BNT taraf 5\%. Menurut Banuwa (2016), teknik pengelolaan tanah yang akan menurunkan laju aliran permukaan, biasanya akan menaikkan selektivitas erosi terhadap partikel-partikel tanah yang kecil seperti liat, tetapi dapat menekan erosi dan kehilangan unsur hara. Pernyataan tersebut didukung oleh hasil penelitian Banuwa (1994) di DAS Citere, Pangalengan Jawa Barat yang menunjukkan bahwa pada erosi yang kecil nisbah pengayaannya tinggi tetapi kehilangan unsur hara secara keseluruhan tetap kecil.

Perlakuan olah tanah minimum dapat menekan erosi karena adanya pemberian mulsa dari sisa tanaman musim tanam sebelumnya dan pengolahan tanah tidak dilakukan pada keseluruhan lahan, sehingga terdapat vegetasi yang menutupi permukaan tanah. Menurut Arsyad (2010), vegetasi dapat menahan air hujan yang jatuh pada permukaan tanah sehingga dapat mengurangi laju aliran permukaan. Laju aliran permukaan yang rendah akan menghasilkan erosi yang rendah. Erosi yang rendah menekan kehilangan unsur hara dan bahan organik tanah.

Perlakuan pemberian herbisida (H1) pada variabel N-Total, P-Tersedia, K-dd, Ca-dd, Mg-dd, dan C-Organik yang hilang akibat erosi cenderung lebih tinggi dibandingkan perlakuan tanpa pemberian herbisida (H0). Besarnya kehilangan N-Total, P-Tersedia, K-dd, Cadd, Mg-dd, dan C-Organik akibat erosi secara berturutturut pada pemberian herbisida (H1) adalah sebesar $0,0612 \mathrm{~kg} \mathrm{ha}^{-1}, 0,0022 \mathrm{~kg} \mathrm{ha}^{-1}, 0,0116 \mathrm{~kg} \mathrm{ha}^{-1}, 0,0107 \mathrm{~kg}$ ha $^{-1}, 0,0051 \mathrm{~kg} \mathrm{ha}^{-1}, 0,7643 \mathrm{~kg} \mathrm{ha}^{-1}$, sedangkan tanpa pemberian herbisida (H0) sebesar $0,0403 \mathrm{~kg} \mathrm{ha}^{-1}, 0,0009$ $\mathrm{kg} \mathrm{ha}^{-1}, 0,0055 \mathrm{~kg} \mathrm{ha}^{-1}, 0,0044 \mathrm{~kg} \mathrm{ha}^{-1}, 0,0021 \mathrm{~kg} \mathrm{ha}^{-1}$, 
$0,3536 \mathrm{~kg} \mathrm{ha}^{-1}$. Total kehilangan unsur hara dan bahan organik pada pemberian herbisida $(\mathrm{H} 1)$ keseluruhan variabel sebesar $0,8551 \mathrm{~kg} \mathrm{ha}^{-1}$, sedangkan tanpa pemberian herbisida (H0) sebesar $0,4068 \mathrm{~kg} \mathrm{ha}^{-1}$.

Peningkatan kehilangan unsur hara dan bahan organik tanah pada perlakuan pemberian herbisida (H1) terjadi karena erosi yang dihasilkan cenderung lebih tinggi dibandingkan tanpa pemberian herbisida (H0). Hal tersebut karena pemberian herbisida menyebabkan vegetasi tanaman penutup tanah berkurang, sehingga permukaan tanah menjadi lebih terbuka dan tanah mudah tererosi. Hal ini juga menunjukkan bahwa pemberian herbisida yang membuat gulma mati dan menjadi mulsa yang diharapkan dapat menekan erosi ternyata belum mampu menurunkan laju aliran permukaan saat terjadinya hujan. Aliran permukaan pada perlakuan pemberian herbisida lebih besar dibandingkan tanpa pemberian herbisida. Aliran permukaan yang lebih besar menyebabkan erosi menjadi lebih besar, sehingga dapat meningkatkan kehilangan unsur hara dan bahan organik tanah.

\section{KESIMPULAN}

Kesimpulan penelitian ini adalah perlakuan sistem olah tanah berpengaruh nyata terhadap kehilangan $\mathrm{Mg}$ dd dalam sedimen. Perlakuan herbisida tidak berpengaruh nyata pada variabel $\mathrm{N}$-total, $\mathrm{P}$-tersedia, $\mathrm{K}$ dd, Ca-dd, Mg-dd dan C-organik dalam sedimen. Tidak terdapat interaksi antara perlakuan sistem olah tanah dan pemberian herbisida pada variabel N-total, Ptersedia, K-dd, Ca-dd, Mg-dd dan C-organik dalam sedimen.

\section{DAFTAR PUSTAKA}

Adnan, Hasanudin, dan Manfarizah. 2012. Aplikasi beberapa dosis herbisida glifosat dan paraquat pada sistem tanpa olah tanah (TOT) serta pengaruhnya terhadap sifat kimia tanah, karakteristik gulma, dan hasil kedelai. Jurnal Agrista. 16(3): 135-145.

Arsyad, S. 2010. Konservasi Tanah dan Air. Institut Pertanian Bogor. Bogor.

Banjarnahor, R. 2010. Evaluasi Basa-Basa Tukar dan Kapasitas Tukar Kation Tanah yang Diaplikasi Limbah Cair Pabrik Kelapa Sawit di PT SMART Kebun Padang Halaban Labuhan Batu Utara. Skripsi. Universitas Sumatera Utara. Medan.
Banuwa, I.S. 1994. Dinamika Aliran Permukaan dan Erosi akibat Tindakan Konservasi Tanah pada Andosol Pangalengan Jawa Barat. Tesis. Institut Pertanian Bogor. Bogor.

Banuwa, I.S.2013. Erosi. Kencana Prenadamedia Group. Jakarta.

Banuwa, I.S., Andhi, Hasanudin dan Fujie. 2014. Erosion and nutrient enrichment under different tillage and weed control system. Proceedings The Crown Palais New Hankyu Kochi. 2: 120-126.

Banuwa, I.S. 2016. Selektivitas Erosi dan Nisbah Pengayaan. Anugrah Utama Raharja. Bandar Lampung.

Burhannudin. 2015. Pengaruh Sistem Olah Tanah dan Herbisida terhadap Kehilangan Unsur Hara dan Bahan Organik Akibat Erosi di Laboratorium Lapang Terpadu Fakultas Pertanian Universitas lampung. Skripsi. Universitas Lampung. Lampung.

Ekowati, D., dan M. Nasir. 2011. Pertumbuhan tanaman jagung (Zea mays L.) varietas Bisi-2 pada pasir reject dan pasir asli di Pantai Trisik Kulonprogo. Jurnal Manusia dan Lingkungan. 18(3): 220231.

Kartasapoetra, A.G. 2006. Klimatologi: Pengaruh Iklim terhadap Tanah dan Tanaman. Bumi Aksara. Jakarta.

Lumbanraja, J. 2013. Kimia Tanah dan Air: Prinsip Dasar dan Lingkungan. Anugrah Utama Raharja. Bandar Lampung.

Muzaiyanah, S. dan A. Harsono. 2015. Pengaruh Penggunaan Herbisida Pratumbuh dan Pascatumbuh terhadap Pertumbuhan Gulma dan Tanaman Kedelai. Prosiding Seminar Nasional Hasil Penelitian Tanaman Aneka Kacang dan Umbi 2015. Balai Penelitian Tanaman Aneka Kacang dan Umbi. Malang.

Sembodo, D. 2010. Gulma dan Pengelolaannya. Graha Ilmu. Yogyakarta.

Sutanto, R. 2002. Penerapan Pertanian Organik. Kanisius. Yogyakarta.

Utomo, M., H. Buchari, dan I.S. Banuwa. 2012. Olah Tanah Konservasi: Teknologi Mitigasi Gas Rumah Kaca Pertanian Tanaman Pangan. Lembaga Penelitian Universitas Lampung. Bandar Lampung. $94 \mathrm{hlm}$. 
Utomo, M. 2015. Tanpa Olah Tanah. Graha Ilmu. Yogyakarta.

Utomo, M., Sudarsono, B. Rusman, T. Sabrina, J. Lumbanraja dan Wawan. 2016. Ilmu Tanah: Dasar-Dasar dan Pengelolaan. Prenadamedia Group. Jakarta. 